\title{
How was the traditional makam theory westernized for the sake of modernization?
}

\section{Okan Murat Öztürk}

Ankara Music and Fine Arts University, Department of Musicology, Ankara, Turkey

mozturk@mgu.edu.tr

\begin{abstract}
In this article, the transformative interventions of those who want to modernize the traditional makam theory in Westernization process experienced in Turkey are discussed in historical and critical context. The makam is among the most basic concepts of Turkish music as well as the Eastern music. In order to analyze the issue correctly in conceptual framework, here, two basic 'music theory approaches' have been distinguished in terms of the musical elements they are based on: (i.) 'scale-oriented' and, (ii.) 'melody-oriented'. The first typically represents the conception of Western harmonic tonality, while the second also represents the traditional Turkish makam conception before the Westernization period. This period is dealt with in three phases: (i.) the traditional makam concept before the 'modernization', (ii.) transformative interventions in the modernization phase, (iii.) recent new and critical approaches. As makam theory was used once in the history of Turkey, to convey a traditional heritage, it had a peculiar way of practice and education in its own cultural frame. It is determined that three different theoretical models based on mathematics, philosophy or composition had been used to explain the makams. In the $19^{\text {th }}$ century, Turkish modernization was resulted in a stage in which a desire to 'resemble to the West' began to emerge. Starting from the last decade of that century, the makam conception was also exposed to some transformative interventions for the sake of modernization. First, it was compared with the concepts of Western musical theory such as scale and tonality. At this stage, the scale-oriented theory of harmonic tonality was seen as a complete and excellent model for the 'new/modern' theory desired to be built for the makam. Leading modernizers, Yekta, Ezgi, and Arel did not see any drawback in interpreting traditional makam frets/tones as the European tonal scale degrees with harmonic functions. Moreover, they also regarded those transformative interventions as necessary progress in order to modernize the makam theory. In particular, the model put out by Arel has been accepted and used for many years by researchers, educators and musicians either domestic or foreign as the only modern theory of Turkish music. However, the flawed and incomplete aspects of this theory, which has been constantly contradictory with actual musical performances, have caused 'crisis', and have been subjected to multidimensional criticisms, at least for the last fifty years. Demonstrating the arguments of new discussions on the subject, here, it has been revealed that the concept of makam should be understood as a melody-oriented approach, particularly considering the historical course of the concept in the Ottoman world. As a conclusion, it is suggested that the former reputation and validity of the melodic motion-oriented makam theory, which has been developed since the 15th century in the Ottoman world, should be returned. This step should also be taken as a starting point for new theoretical studies.
\end{abstract}

\section{Keywords}

makam, music theory, melody-oriented approach, Turkish modernization, shifting paradigms 


\section{Geleneksel makam teorisi modernleș(tir)me uğruna nasıl ba- tılılaştırıldı?}

\section{Özet}

Bu makalede, Türkiye'de yaşanan Batılılaşma sürecinde, geleneksel makam teorisini modernleștirmek isteyenlerce yapılan dönüştürücü müdahaleler, söylem analizi temelinde ve eleștirel bağlamda tartışılmaktadır. Makam, Türk müziğinin olduğu kadar Doğu müziğinin de en temel kavramları arasında yer alır. Meseleyi kavramsal çerçevede doğru bir şekilde incelemek maksadıyla burada, dayandıkları müzik unsurları açısından iki temel müzik teorisi yaklașımı ayırt edilmiștir: (i.) dizi-merkezli ve (ii.) melodi-merkezli. Bunlardan ilki, tipik olarak Batı armonik tonalitesine özgü kavrayışı temsil ederken, ikincisi de Batılılaşma dönemi öncesindeki geleneksel Türk makam kavrayışını simgeler. Bu dönem üç başlık altında ele alınmıştır: (i.) 'modernleş(tir)meden önceki geleneksel Türk makam kavrayıșı, (ii.) modernleş(tir)me evresindeki dönüştürücü müdahaleler, (iii.) son dönemlerdeki yeni ve eleştirel yaklaşımlar. Makam teorisi, Türkiye tarihinde bir zamanlar geleneksel bir mirası iletmek amacıyla kullanıldığından, kendi kültürel çerçevesi içinde, kendine özgü bir uygulama ve eğitim tarzına sahipti. Modernleşmeden önce makamları açıklamak için matematik, felsefe veya kompozisyona dayalı üç farklı teorik modelin kullanıldığı belirlenmiștir. 19. yüzyılda, Türk modernleșmesi, 'Batı'ya benzeme' arzusunun tezahür etmeye başladığı bir aşamaya ulaştı. Bu yüzyılın sonlarından başlayarak, makam kavrayıșı da bazı dönüştürücü müdahalelere maruz kaldı. Önce, Batı müzik teorisine özgü dizi ve tonalite gibi kavramlarla mukayese edildi. Bu aşamada, armonik tonaliteye özgü dizi-merkezli teori, makam için inşa edilmek istenen 'yeni/modern' teori için tam ve mükemmel bir model olarak görüldü. Yekta, Ezgi ve Arel gibi önde gelen modernleştiriciler, geleneksel makam perdelerini, armonik işlevlere sahip Avrupa tonal dizileri olarak yorumlamakta herhangi bir mahsur görmediler. Dahası, bu dönüștürücü müdahaleleri, makam teorisini modernleştirmek adına zorunlu bir ilerleme olarak da kabul ettiler. Özellikle Arel tarafından ortaya konulan model, uzun yıllar boyunca, yerli veya yabancı araştırmacı, eğitimci ve müzisyenler tarafından, Türk müziğinin yegâne modern teorisi olarak kabul görmüș ve kullanılmıştır. Ancak, gerçek müzik icralarıyla devamlı surette çelişen bu teorinin kusurlu ve eksik yönleri, onun 'kriz' içine girmesine ve en azından son elli yıldır, çok yönlü eleştirilere tabi tutulmasına neden olmuştur. Konuya dair yeni tartışmalardaki başlıca görüşler ortaya konulmak suretiyle burada, makam kavramının, özellikle Osmanlı dünyasındaki tarihsel seyri de göz önünde bulundurularak, melodi-merkezli bir yaklaşımla anlaşılması gerektiği açıkça ortaya çıkmıştır. Sonuçta, Osmanlı dünyasında 15. yüzyıldan itibaren geliștirilen melodik harekete dayalı makam teorisine, eski itibar ve geçerliliğinin iade edilmesi ve bu adımın, yeni teorik çalışmalar için başlangıç alınması gerektiği öne sürülmüștür.

Anahtar kelimeler

makam, müzik teorisi, melodi-merkezli yaklaşım, Türk modernleşmesi, paradigma değişimleri

\section{Introduction: "Turkish moderniza- tion" as the basis for cultural trans- fomation}

In order to understand why those who want to modernize the traditional makam theory by taking Europe as model have entered such an orientation, first of all, it is necessary to take into account the process defined as the "Turkish modernization'. Turkish modernization, which started in the late 18th century in the Ottoman Empire, has basically developed depending on two reformative conceptions. The historian Stanford Shaw, bases these conceptions on the 
preference of two opposite reforms as 'traditionalistic' and 'modern' (1977 1, 55). In traditionalistic reform process, the methods such encountered as the 'amelioration of the tradition', 'elimination of defects of the tradition' and 'revival of the past' had been tried to solve the various problems. The typical and the last representative of this conception was Sultan Selim III who came to the sultanate in 1789 . By realizing a series of reforms, Selim III wanted to modernize the Ottoman system, which lost power against Europe. However his efforts of reformation have failed and he lost his life as a result of the assassination during a major uprising at 1808 . At the same time, this rebellion was the end of the traditional reform' conception.

The efforts of the Europeanization of the Ottoman military and administrative systems took place in the period of Sultan Mahmut II (1808-1839) who represents 'modern reform' conception. The concept of 'tradition' was seen as a factor, which should be abandoned by this understanding. The process continued until the establishment of modern Turkish Republic through the some stages of administrative and political reformations such as Tanzimat, Islahat and Messrutiyet in the Ottoman Empire. Mardin (1999, 15) draws attention that Sultan Abdülhamid II (1876-1909) took the West as a 'model' to himself for the innovations he wanted to achieve. But in the years of the Second Constitutional Era (1908-1918) when particularly, the Committee (and Party) of Union and Progress was in power (1909-1918), the idea that the West was 'the superior and the only civilization' was widely adopted. "[T]he Young Turks", Ahmad says, "[...] not only changed the political system but they also attempted to refashion society by borrowing more freely from the West than ever before" $(2003,31)$. It is a fact that 'Europeanization' and
'Westernization' are often used and understood synonymously with 'modernization' in Turkey. The makam concept within traditional Turkish music has been one of the most affected issues by these processes. In this context, Turkish modernization defines a process that has developed with the efforts of adoption and dissemination of Western music and the modernization of traditional Turkish music by transformative interventions.

\section{Makam: Conceptual frame}

Makam that is derived from Arabic maqam, means 'place', 'location', 'position', 'situation/state', 'station/stop' or 'gradation' in Turkish. The conception of makam, in which context it is taken into account, in the end, it cannot be considered separately from the concepts of space and motion. This conception is a way of knowing which is focused on some definite referential points such as beginning, progressing, and ending of any motion within a certain space. It is noteworthy that the word makam has a widespread use not only in music, but in Sufism as well. In Sufi terminology, makams are understood as definite 'stations' of the 'mystical path to reach to God' (Knysh 1999, 303-306). In this regard, the makam means primarily 'the place being resided / rested / reached / stopped'. It clearly means at the same time 'having a particular place of its own'. This meaning of the word corresponds to a certain fret/tone in musical space bounded by the fret/tone/sound system. Therefore, the makam conception is directly related with the concepts of 'space', 'motion' and 'stop/final' in music. If the concept of melody, in general sense, is understood as 'motion' in musical space, the makam concept corresponds to the stopping, staying, or resting places (frets/tones) which are references to this movement. In this context, it is remarkable in all respects that the simi- 
larity between 'melody and makam' in music is also present between the concepts of 'state and station' ('hal ve makam') in Sufism. Conceptually, it is clear that there is a complementary relationship between 'makam, station, and resting on' against 'melody, state, and motion'. In his doctoral dissertation on the metaphorical logic of 'musical motion and space', Arnie W. Cox, has reached the following 'conceptual' observations, which can be interpreted perfectly in terms of the makam: "states are locations [...] musical states are musical locations [...] change of state is motion between states [...] change of musical state is change of musical location" (1991, 256). In traditional makam theory, the 'states/locations' correspond to the beginning and ending 'frets/tones', while the 'motion' is expressed/defined by seyir (progression) 'between' those two 'central' tones. In addition, it can be said that there are two main factors in traditional Turkish music that coincide with the observations of Cox (1991) and reinforce the meaning of the makam word. The first is the states/positions of the perdes (frets) on the neck of the fretted instruments such as tanbur, lavta or bağlama. Because of frets, each makam has a definite 'place/location' on instruments. That's why makam has the same meaning with the position especially for the instrument players. It always means 'string - fret - finger'. It is necessary to remember here that the term used to classify melody styles was perde (Persian pardeh) before the 14th century when the concept of makam began to become widespread (Dzhumajev, 1992). Famous theorist Abd al-Qadir al-Maragi expresses this relationship in a clarity that does not need any interpretation: "musicians (or masters of music) use the twelve perdes for the twelve makams. The Arabs call them as shudud and give also special names to each one" (Sezikli 2007, 170). It should also be noted here that the $12^{\text {th }}$ century theorist Muhammed Nishaburi/Naysaburi built his makam theory on the term of perde (Dzhumajev 1992; Fallahzadeh 2005, 110-115).

The second factor is particular locations of the makams in traditional two-octavetone-system. There is a strong relationship between perde and nağme in the makam conception. For makam, some notes/tones play a key role in positioning and development of some unique tunes and melodies. Initial tone (ă̆az perdesi) and final tone (karar perdesi) are the important ones of those. The Ottoman music theoretical manuscripts from the $15^{\text {th }}$ century to the early $20^{\text {th }}$ century clearly show that makam was basically described in terms of the 'manner/mode' of a 'melodic motion' between initial and final tones (Öztürk 2014a, 2014c, 2018). Therefore in determination of the place of a makam, the initial and final tones stand out as decisive factors. However in time, the final tone has gradually become the only factor to determine the placements of the makams. Thus, it is understood that the ending locations of the melodies are also the keys to determine the place of a makam in traditional fret/tone system. In the $15^{\text {th }}$ century Turkish sources on music theory, there are some special expressions used for the ending such as karar, karargah, mahatt, and so on. But karar is the most common use among them in those sources. Karar literally means 'to decide' or 'making a decision'. In addition, particularly in the $15^{\text {th }}$ century musical writings, it's noteworthy that some expressions like 'to rest', 'to come and sit', 'to arrive and rest' are used for ending. In this way, the concept of karar is used synonymously with the expressions of 'to stop', 'to stay', 'to sit' and 'to rest'. As can be clearly seen, karar is where the melody 'ends' or 'rests' or 'sits and stays' or 'stops'. The close relationship between makam and karar 
(ending) enabled the development of a new theoretical paradigm.

There are differences between theoretical and practical aspects of makam concept in today's Turkey. While the concepts of interval and scale are the keys in 'westernized' theoretical side of the makam, fret/tone, tune/melody and course/motion are effective for the practical and historical side of it. Also very well known, being one of the basic issues in traditional Turkish music, the makam has also become a point of a growing interest in the international area (Aoyagi 2001; Ederer, 2011; Feldman 1996; Signell 1977, 2002, 2008; Stubbs 1994; Wright 1990, 1992, 2000). Therefore the ICTM (International Council for Traditional Music) has a special Study Group, which completely focused on this issue (Elsner 1989; Elsner and Jahnichen 1992, 2006, 2008; Elsner and Pennanen 1997; Elsner, Janichen and Talam, 2014; Elsner, Janichen and Güray, 2016; Powers 1988). The concept of makam still retains being the core subject and very controversial issue particularly in music theory.

\section{Two worlds, two music theoretical systems in music}

According to Jeff $\mathrm{T}$. Titon and Mark Slobin, 'music cultures' can be understood as different 'music worlds' (1992, 1). One of the most effective pioneers of the modernization of Turkish music, Rauf Yekta, penned an article on Turkish music for the famous French encyclopedia Lavignac in 1913 (published in 1922) and referred: "If any musicologist of our time wanders to investigate the civilized countries and music of various nations, the existence of two main types of music will be observed: 1 . Western music that is called European music, 2. Eastern music" $^{\prime \prime}(1986,17)$. Co Chair of the ICTM Study Group on Maqam, Prof. Dr. Elsner uses the expression of the 'maqam-world' for cultures that use the makam concept
(Powers 1988, 199). In addition to these, it's known that there are two different conceptions, 'modal' and 'tonal', in Western music history (Wienpahl 1971; Powers 1981).

Inspired by these categorizations I discuss the concept of makam here, in terms of two different approaches. Thus two basic concepts that I have used here, symbolize two different music worlds 'theoretically': (i.) Scale-oriented approach, (ii.) Melody-oriented approach. Of these, while the scale-oriented one typically represents to Western harmonic tonality theory, melody-oriented one symbolizes the theory of makam of 'traditional' Ottoman and Turkish music. Scale-oriented approach is a product of Western-oriented theorists who undertook the task of modernizing 'Turkish music' in guidance of 'positive (European) science'. According to them, the makam was essentially nothing more than an octave-scale loaded with harmonic tonal functions, as in Western music theory. The keywords of this approach are 'interval, scale, octave, major, minor, tetrachords, pentachords, degree, tonic, dominant, subdominant, function, harmony', and so on. The main source of the melody-oriented approach, which is emphasized by the writer, is that of the traditional makam theory itself that has been shaped since the 15th century in the Ottoman world and has given the distinctive quality to Turkish music. This approach, which refers to the tradition itself and which has the goal to understand it better, is based on the multifaceted relations between frets, tunings, tunes/melodies and the makam concept. The keywords of this approach are perde (fret/tone/note), nağme (tune/melodic motive), düzen (tuning, adjustment) ağaz (initial), karar (final), seyir [course (melodic movement or progression)], and so on. The written sources of the Turkish music, its living repertoire and the tradi- 
tional performance practices; all of them are the main components of this approach.

\section{The makam concept and shifting paradigms in Turkey}

Thomas Kuhn dealt with the concept of paradigm with his famous work Structures of Scientific Revolutions (1970), and explained it as the prevailing view of science between the scientific communities in certain periods. In terms of information, paradigm is a set of the principles, rules, explanations, applications and even the beliefs that are believed to be valid in a certain period. Therefore paradigms change in time. He separates the paradigm changes into three stages: the stage of normal science, the stage of crisis and the emergence a new paradigm. If 'valid' or 'existing' paradigm enters into the crisis, scientific communities tend to seek a new paradigm (Kuhn 1970, 84-85, 90-91).

Because it is an 'art' based on performance, there is no obligation to make music with 'only' theoretical knowledge. It can be made in a perfect way also without knowing any theory at all. $\mathrm{Mu}-$ sic theory is an epistemological field in which definition, information, explanation and classification activities are valid. It is a priority issue only for those who want to know and explain what happening in music is and what the elements of music are. For this reason, it is possible to understand those who work in the field of music theory as a kind of scientific community in the sense that Kuhn means.

We can clearly see that theorists have adhered to different theoretical models when we turn to the sources that illuminate the history of the makam theory. It is actually possible to identify those models through four basic criteria. According to Öztürk (2014c), those criteria are the followings: (i.) the main concept, (ii.) explanation style, (iii.) classificatory categories, and (iv.) terminology. In the light of these criteria he determined that four different theoretical models in the history of makam theory have been developed up to now. It is seen that the basic concepts that the models depend on are (i.) cycle/circle, (ii.) makam, (iii.) makam and course/motion, and (iv.) harmonic tonal scale and course/motion. While the first and fourth models are scale-oriented, the second and third ones are melody-oriented. In the second model, esoteric symbolism is valid, while in the third, composition and work are the forefront. So the second model aims to describe and to classify the existing melodies, while the other has become as a guide for the works to be composed.

It has experienced radically interventions during the Turkish music modernization in the field of traditional makam theory. It is a fact that there are different theoretical models in the history of the concept of makam in Turkey. It is possible to investigate these models under three main headings:

\section{Pre-Modernization era: Historical makam conception /from $15^{\text {th }}$ century until the first quarter of $19^{\text {th }}$ century)}

\section{Pre-Ottoman time}

Ottoman sources began to emerge by the 15 th century. In these sources, which developed within 'tradition', different approaches/models are seen to be salient in dealing with the makam concept. Those manuscripts are basically the ones who referred to the 'Systematist School' developed in Islamic culture. Safi al-Din al-Urmawi is considered as the founder of this school (Wright 1978). However in the source of knowledge represented by the school located a deep-rooted tradition starting with al-Kindi's translations from Greek to Arabic in $9^{\text {th }}$ century (Shehadi $1995,20,40)$. So that, the traces of this 
tradition can be seen in the Ottoman world, up to the end of $15^{\text {th }}$ century (Farmer 1986; Can 1993, 2001). The various works which belong to Al-Kındi, AlPharabius, Brethren of Purity and Avicenna, formed the basis of this school. Safi al-Din al-Urmawi, Qutb al-Din alShirazi and Abd al-Qadir al-Maragi became the leading representatives of this tradition in Islamic world. When this tradition is approached from the perspective of concepts which provide sound organization, the mere concepts of the paradigm are observed as circle (daire) and cycle (devir). Circles are symbolic and speculative signs which are based on 'interval ratios' and 'numerical harmony or concordance'. The theory of circle, with its basic principles and symbolic features seems to be an extension of old belief systems like Hermetic and Pythagorean tradition in Islamic culture (Öztürk 2012a, 2014a, 2014b, 2014c). Some theoretical topics (the division of octave, the formation of 'two-octavesystem', genus, consonance and dissonance criteria, and so on) are the main components of this paradigm. Cycles are the products of cosmo-chrononaturalistic symbolism of Pythagorean tradition (Godwin 1993). Cycle is a sequence based on 'intervals' and 'consonance'; it is not identical with the conception of makam. In this paradigm, music is considered together with arithmetic, geometry and astronomy as quadrivium, four fundamental sciences of Pythagoreans. For this reason, in the tradition of the Systematist School, cycles are the representative of the network of relationships. Circle not only symbolizes 'celestial bodies', but also a geometric surface, the cycling character of sounds, arrangement of intervals in an order, the journey of the human soul and the 'stars' which are formed by the true combination of parts of consonant intervals. The theory of circle, with its utmost symbolism, basically carries a modular charac- ter. The melodic fourth and fifth intervals, which constitute the sub-segments of the theory are combined in various ways to form the circles. At this point, most of the circles denote not the 'real' tone clusters used in music practice, but the 'probable tones' obtained through a cognitive process. The key concepts of the circle paradigm are 'octave divisions', interval, genus, circle, consonance and dissonance. However, it is seen that most of these concepts either do not exist or were subject to change in content of makam theory.

\section{Ottoman Music Theory Treatises:}

Ottoman manuscripts are basically the ones, which reflect the multi-cultural inheritance of the empire although they made references to the prominent authors of the Systematist School. Hence, the $15^{\text {th }}$ and $16^{\text {th }}$ centuries present important diversifications from the previous traditions as far as the makam theory was concerned. With a highly functional distinction made by Al-Ladiqi Mehmed at the end of the 15th century, I find appropriate to diverge the sources of this era into two distinctive groups with respect to contents, which are salient in their theoretical orientations. The first one is 'the masters of science' group, whose octave calculations and intervals were based on Pythagorean theory (Öztürk 2008; Tura 1988). The second group is the 'masters of art/practice', which explain the makams as fret (perde), fret/tone system, tuning (düzen) and 'melodic motion manner' (seyir/reviş/eda). The term makam of which the first usage was seen in Abd alQadir al-Maragi is one of the basic terms of Ottoman sources in these centuries. Al-Ladiqi, who was one the last representatives of the Systematist School tradition in the Ottoman world and who exploited Safi al-Din and Abd al-Qadir's works use the 'circle' and 'cycle' terms together. Makam, in the works of this 
period, was described as starting from a certain initial tone (ağaz), wandering around the other frets of a tuning (seyir) and finally ending in a certain final tone (karar). In other words, Ottoman sources preferred a different paradigm focused on the 'manner/mode of the melodic motion' (Öztürk 2014c, 2015b, 2016a, $2016 \mathrm{~b})$. In the sources written by 'the masters of art/practice', such as Kırşehirli Yusuf's Risale-i Musiki [1411?], Bedri Dilşad's Muradname [1426], Hızır bin Abdullah's Kitabü'l-Edvar [1440], Kadızade Tirevi's Risale-i Musiki [1492] and Seydi's Matla [1504], makams were clearly separated from the mathematical and speculative aspects of Pythagoreanbased the Systematist tradition. However, it is also stated that these writers continue to adhere to the 'four element' symbolism. (Can 2002; Öztürk 2012a, 2014a, 2014b). Few in number though, Al-Ladiqi Mehmed, Fethullah Şirvani and Alişah bin Hacı Büke tried to be in line with the principles and the content of Systematist school tradition. In addition, in these sources the concept of 'ethos' which was transmitted from ancient Greek to Ottomans via Islamic culture was seen important as the makam practice is concerned: which makam is to be used at which hour of the day; which makam suits to certain hues of skin in human; which makam should be used for what kind of characters in human; which makam is to cure which illnesses are all typical topics of makam and ethos relationship (Can 2002). Such musicoteraphy contexts were still seen in the works of court doctor, Gevrekzade Mehmed Efendi in $18^{\text {th }}$ century and in Haşim Bey in $19^{\text {th }}$ century. In the works of Kırşehirli Yusuf and Hızır bin Abdullah, the way the makams are handled and conveyed makes them distinguished among the other names mentioned above. Especially the tetrachord, as they mentioned 'yekgah, dügah, segah, and çargah' ('prime, second, third, and fourth') point to the multi-cultural aspect of Ottoman world and gives the impression that these sources carry some other influences. Within this frame, the similarity between Hızır bin Abdullah's four-fret based explanation style and 'enchiriadis', which reflects the Byzantine church practice are remarkable /Öztürk 2012a, $2014 a, 2014 b$ ). The main terms of this era is makam (melodic manner/mode), terkib (compound melodic manner/mode), avaze (voice/tone), şube (branch), perde (fret/note/tone), düzen (tuning), nağme (tune, melody), ağaz/mahrec (initial), seyir/reviş (motion/progression/walking), karar/mahatt (final), nerm (low, Lat. durus), tiz (high, Lat. molle), and so on. As seen, sources of this century have a differentiated paradigm from the previous era.

\section{Renewal of the Tradition:}

An important change in the paradigm concerning makam was fulfilled in the $18^{\text {th }}$ century by the modernizing works of Kantemiroğlu and Abdülbaki Nasır Dede. What these works shared in common was that they did come out with a new classification, term and explanations concerning makam. Final tone is thought to lie in the centre of this paradigm. Analyses and explanations of makams are placed in a 'final tone-centered' frame. These sources went on explaining makams in a 'motion/course-oriented' manner. Here, makam is related with 'tune/melody' and 'melodic motion'.

To illustrate, Kantemiroğlu (2001) divides makams into two; müfred (main or independent) and mürekkeb (compound). In addition to these, he establishes subcategories over final tone, fret characteristics (complete or incomplete frets) and the position in the system (makams of the lower tones, makams of the higher tones, and makams of the incomplete frets (in ascending and in descending, and so on). While explaining the makams, he gives different 'routes'. He used some 
explanatory terms such as kutb (center), ağaz (initial), seyir (motion), temam perde (main/complete tone), nim perde (half/incomplete tone), karar verme (rest on), istirahat etme (resting), çıma (ascending), inme (descending), hükm (range), tabiyet (subjection). The way he transmits the knowledge is completely changed into dealing with and explaining terms, though it sometimes reuse various terms of former periods (Feldman 1996; Kantemiroğlu 2001; Popescu-Judetz 1999; Wright 1992, 2000).

Abdülbaki Nasır Dede (1794) directly defines makam as 'melody' (lahn). His definition has probably been one of the most satisfying and meaningful descriptions made throughout the history of makam theory. His makam conception must be regarded as one of the most satisfying and meaningful statements made throughout the history of the theory: "Makam is melody that shows its own integrity when it is heard with its essential materials and can not also be likened to any other one" (1794 v. 8b; 2006, 34; Aksu 1988, 156-57). He claims that some extra frets, which he called müzeyyen (ornamental), were necessary, since the makams do not have adequate number of frets (Başer 1996; Tura 2006). This assertion is quite parallel with Kadızade's description of makam at the end of $15^{\text {th }}$ century (Öztürk 2014c, 2016a, 2018a). Nasır Dede made discrimination between makams and compounds (terkibat). He deliberately stated in some parts of his works that he used a new terminology on language, terms and descriptions. Consequently, it is obvious that Nasır Dede has a maqam understanding, which is focused on the melody, melodic features and the manner of the melodic motion.

In this period, it is clearly seen that the field of composition passed the previous theoretical knowledge; realizing and experiencing new applications gained more importance in terms of innovation in art.
Developing new makams and usuls, composing new compound melodies, making more modulations in musical works have been the dominant feature of this period. It can be seen that the concept of seyir (melodic course/progression) in this period has completely meant strategies to compose new musical works (Öztürk 2014c, 2017). Therefore, from the 18th century onwards, the concept of seyir itself has begun to be understood as a potential 'generative' issue in terms of composition. Stubbs makes the following assessment for the concept of seyir, based on his own learning experience: "According to the way I observe this term used by my teachers, seyir is the selfgenerative principle of makam that comes into play during improvisation (and also in other types of composition)" (1994, 117).

\section{Transformations during westernization process (from the first quarter of 19th century to present day)}

\section{The last era of Ottoman Empire}

In his article comparing Japan's and Turkey's modernization periods, Karl Signell asks if the modernization is "the same as Europeanization" and he gives that answer: "[...] musically speaking, modernization and Europeanization are not the same" $(1976,72,88)$. As previously stated, the efforts of modernization started in the last years of the $18^{\text {th }}$ century and they were transformed into an open Europeanization in the 19th century. Especially, in the proper sense the era of Sultan Abdülmecid had been an Europeanization era due to the attitudes of the Ottoman dynasty. From the end of the nineteenth century, it is seen that in political and ideological writings which criticizing the Ottoman lifestyle, European or Western civilization have always been referenced and exalted.

In his article discussing the Western music influences on non-Western cultures, 
Bruno Nettl defines Westernization like "to become a part of the Western system by adapting the basic characteristics of Western music" (1986, 366). In this regard, it is possible to see the 19th century as a different paradigm during which European music gained a central place and comparisons were made between tonality and makams. The attempts of Ottoman dynasty to Europeanize the government and the elite, gave rise to the European music to gain a central place among those people. Consequently, with the foundation of the Musıka-yl Humayun in 1826, a way was given to the attempts that reinforce the interests towards European music (Aksoy 1985). It is seen that in the 'mecmua' (also known as 'Haşim Bey Edvarı') written by Haşim Bey, who was graduated from that foundation and originally a traditional music composer, educator and performer, the traditional makam definitions were compared with the tonalities of the European music.

For this reason, Haşim Bey is a groundbreaking in Turkish music history with that practice. This century also constitutes the first base of the beginnings of becoming widespread of European notation and theory, starting from court towards musicians of Istanbul. About that topic Owen Wright makes those evaluations (1990, 237): "In the nineteenth century, when the concern was straightforwardly to devise an appropriate form of representation for Turkish makams in Western notation, problems of this nature did not arise. Instructive here is Haşim Bey (1864), which does not itself contain any music, but in which the basic verbal description of each makam, couched in traditional form, is supplemented by a definition of the key/mode signature for it in Western (alafranga) notation. Rast is thus allotted G major, while for a makam such as Neveser, the structure of which approximates to nei- ther major nor minor, Haşim says (1864: 24): alafrangada... na mevcud ise de ... sol minor ta'bir ederler. (Although it does not exist in Western music it is expressed as G minor.)". As it can be seen, theory, knowledge, concept, terminology and rule importation was also started while European notation became widespread. In terms of traditional musicians this centralization gradually shows progress as a 'process of becoming bimusical'.

Rauf Yekta defined makam as 'a special musical scale'. This definition became a pioneer for 'the scale-oriented' makam conception $(1986,67)$. "Present-day theory of Turkish classical music is the result of collaboration by Yekta with the two others, Ezgi and Arel" (Signell 1977, 7). As a 'positivist scientific' pioneer, Yekta lists the requirements for a makam as; (i.) the fourths and fifths, which are 'constituting elements', (ii.) range (he uses the term ambitus), (iii.) the initial, 'dominant' and final tones, (iv.) seyir (melodic progression), and (v.) tam karar (complete ending). Like Haşim Bey, Yekta also compares Turkish makams with Western examples. For instance, about Rast makam he mentions "it is not something else other than European G major" (1986, 69). Despite Yekta's leading role, it is true that the handling of the makam theory with a completely 'western-

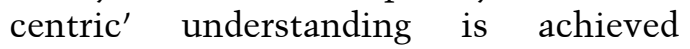
through the cooperation of Ezgi and Arel. In this context, Wright's assessment seems to be quite right: "If there has been one dominant, quasi-official theory for Turkish music in the second half of the twentieth century, it is that particularly associated with Ezgi and Arel" (1990, 224).

\section{Republican period}

In Turkey, the republic was appeared in a 'nation-building' frame as a 'modernization project'. If the development of that process is observed from a musical per- 
spective, it can be seen that the modernization ideal is built entirely on thoughts of Westernization (Aksoy 1997; Behar 2005; Can 2008). As a typical example, Rauf Yekta gave the following expression on the cover of his book, Turkish Music Theory, published a year after the declaration of the Republic: "According to the most recent methods of the science, it is a theoretical and scientific work that aims at specifying the theoretical rules on which Turkish music is based on, and that explains how these rules will be applied to the practice of our national music" (1924, front cover). With all his 'scientific' confidence, he explains what these rules are like: "[t]hese rules are [melodic] fourths and fifths, which has been completely unknown by our musicians until now. In the books written under the name of theory, it has not came acroos any topic related to those formations which form the basis of music theory" (Yekta 1924, 48). Suphi Ezgi, one of the prominent modernists, did not hesitate to accuse the 'old' Ottoman theorists of the makam conceptions that they were entirely contrary to 'science and logic' $(1933,188)$. It is clear that the positivist tendencies of 'the modernizers' have, are the greatest obstacle in front of their understanding of previous melodycentered theories. It is also clear that the main priorities of 'the modernizers' were not to understand better the old theories. On the contrary, they gave more importance to modernizing the makam theory 'without wasting time'.

The primary effects and indicators of modernization interventions for music outside the field of theory are: (i.) western choir and orchestra practices have been regarded as a model for traditional music performances, (ii.) performances with a conductor, (iii.) using western notation, (iv.) wearing 'bow tie' and 'frock', (v.) adding violin, cello, piano and clarinet to traditional instrument en- semble, and so on. In addition, the instrumental virtuosity has been related to playing chords, arpeggios, chromatic passages, ascending and descending scales and accompanying the melody with parallel thirds and sixths. The makam choice was started according to its compatibility with western temperament system. Harmonic accompaniment has become widespread. Melodic leaps with third and fifth intervals which are not common in traditional melodic texture, rather characterizing Western music; chromatic progressions; tonal cadence relations; knowing Western theory; learning notation; recognizing major and minor tones; trying to learn and define makams according to those structures. All those indicated factors and many other ones consists only some part of the effects of westernization to Turkish $\mathrm{Mu}-$ sic.

As noted by Signell: "With the passing of the Yekta-Ezgi-Arel era, theory has fallen into an almost somnolent state. Arel students and others have made a few efforts to prolong the impetus and vigor of those times, but the spark seems to be dying. If anyone is preparing a major contribution to current Turkish music theory, it is a well-kept secret" $(1977,8)$. In fact, not only Arel but also nearly all of the pioneer Turkish music theorists of the Republican period could not avoid seeing the makam tradition with their 'Western glasses' (Tanrikorur 1998). All of the theorists like Abdülkadir Töre, Ekrem Karadeniz, Mildan Niyazi Ayomak, Kemal ilerici, şefik Gürmeriç, ìsmail Hakkı Özkan continued to consider makam as a scale-oriented conception (Aksoy 1997; Öztürk 2006, 2014c). In today's context, this trend continues to be existent among the efforts trying to further westernize the Turkish music theory (Yavuzoğlu 2008).

Actually, if today's theory is observed, it can be seen that the theory has an eclec- 
tic structure. In this respect, it seems like a 'patchwork', which is constituted by gathering different features of Turkish music and western music theories. For example, all of the tetrachords and pentachords that develop the makam 'scales' of Arel theory were 'chosen' from the tradition of Safi Al-Din. The makam classification like basit (simple), bileşik (compound) and şed (transposed) was mainly taken from Kantemiroğlu. The thought of comparing makams with major and minor scales of the European music was taken from Haşim Bey. The contents and the language of the theory had been entirely taken from Europe. The 'subject titles' of Arel theory, which is being used as today's 'quasi-official' Turkish music theory, are the concepts and terms like interval, tone, inversion, scale, function, tonic, dominant, subdominant, sensible and modulation.

\section{Recent trends and new approaches}

One of the most important pioneers of new trends is the eminent musicologist and composer, Yalçın Tura. His interest on the historical Turkish music sources pioneers the studies on that field. First of all, Tura (1988) considerably criticized the inadequacies and obstructions of Arel's paradigm. Aksoy (2000), Behar (1987, 2005), Tanrikorur (1998), Signell (2008) and Wright (1990) are among those who criticize Arel's 'frozen' theory as well. The researches using 'tradition' as a reference point for a better understanding of the makam, are made by scholars like Cenk Güray (2011), Cihat Can (1993, 2001, 2008), Emrah Hatipoğlu (2011), Öztürk (2008, 2010, 2012b, 2014c, 2016a, 2018a), and Oya L. Yilmaz (2002). In particular, Öztürk (2014c, 2015c, 2016b, 2018a) offers and uses a new theoretical frame for the makam concept, namely 'Theory of Tunings and Tunes'. Accordingly, tunings are some limited fret adjustments (or choices) and all kinds of melodies are shaped in those tunings.
Therefore, makams are only definitive and classificatory elements for tunings and tunes/melodies. As a cognitive element, each makam defines a different unique melodic motion manner/mode/behavior. In this context, makam knowledge does not need restrictive ranges such as melodic fourths, fifths or octaves. All melodic manners have some centricities in tunings in terms of their beginning and ending places. Some makams show uni-centricity in melodic sections, while others have double. In tradition, the melodies, which have central notes more than two in formal sections, called as terkib /'compound' or 'mixed' tunes/melodies). All makams and terkibs are known by their specific tunes and tunings.

In his book Makam, Signell (1977) considers it in five components: 1. Stereotyped melodies and sentences, 2. Main tonal centers, 3. Melodic direction, 4. Characteristic modulations, 5. Tessitura. In the 'stereotyped melodies and sentences' part he mentions that: "A local Turkish musician can usually recognize the makam of a piece long time before the final note is arrived, sometimes after only a small introduction. It is seen that mainly this recognition process is directly related to the system of stereotyped melodies and sentences" $(1977,122)$. In the studies he carries on with Münir N. Beken, Signell started to investigate makam and melody relationship in a more detailed way in recent years (Signell 2008). He states that: "The makam system is an open system but any fixed definition of a makam is a closed system. A scholar who looks at a fixed scale which purports to define a makam may find discrepancies between the abstract scale and performed music in that makam" $(2008,185)$. Similarly, Öztürk (2014c) has concretely demonstrated in his doctoral dissertation that the makam theory is, in the end, a spe- 
cialized knowledge and practice on the concepts of perde (fret/tone) and nağme (tune). The makam theory is the product of a different epistemology that focuses on the basic manner/mode of movement of any melody. In this theory, the main purpose is to explain the movement manners of various melodies, which are formed in certain fret/pitch arrangements and tunings (düzenler), by specifying their starting, going and ending places (frets). In this context, he insists on the important and extremely meaningful difference between the fields of theory and composition in the case of the makam.

In recent years, academic studies about the historical sources of Turkish music are also increased in number. Most of those historical sources are being translated and published in the current Turkish. A series of publication under the title 'Adwars as Theoretical Sources of Turkish Music' has been prepared by a committee that I am still a member as well, within General Directorate of Fine Arts (Ministry of Culture and Tourism). With this series, it will be possible to enlighten most of the unknowns about Ottoman-Turkish music culture beside to understand the tradition with a broader perspective. Moreover, with the indicated publication series a contribution will be given to determining the characteristics of 'common knowledge' shared by Ancient Greek, Islam, OttomanTurkish, Medieval European, Iranian, Indian and Arabic cultures. In addition to those, sources written by Armenian and Greek musicians lived in Ottoman world are also begun to appear (Behar 2005; Pappas 1997, 2007; Popescu-Judetz 2000, 2002; Popescu-Judetz \& Ababi-Sirli, 2000). Those sources consider makam concept from their own cultural perspective. For those reasons, I think that a detailed research and publishing activity of historical sources belonging to Otto-
man-Turkish music has a considerable importance for world music history and culture.

Makam tradition has some predefined areas of freedom. Therefore a traditional musician has freedoms like: increasing or decreasing the number of frets utilized; changing the intonation of a fret/tone; interpreting and using any makam in different forms; crossing the borders drawn by known applications; inventing new formulas for makams; finding melodic inventions and innovations; to produce melodies lying out of the standard approach; being free and original in improvisation and melodic production; staying connected to a defined paradigm or not. When all of these factors are considered, it can be stated that the makam practice of Turkish music has a significant effect on the construction of melodies.

\section{Conclusion}

The 'quasi-official' theory regarding makams used in today's Turkish music is radically estranged from its traditional practice due to the westernization attempts activated under the heading of modernization. But even within these circumstances, both the living musical traditions and the knowledge transferred by the written musical materials enlighten the way to a better understanding of the makam concept. A total evaluation of these sources puts forward the central position of the melody for the makam concept.

To be identified the makam concept needs original terms appropriate to its character. In the traditional resources, some basic terms like perde (tone/fret), düzen (tuning), nağme (tune/melody), ağaz (initial), seyir (melodic progression) and karar (final) had been used for definitions of makams in musical theory. In the post-modern world of today, concen- 
trating on the concepts such as 'tradition' and 'meaning' will have contributing consequences in terms of the makam theory. The first of these consequences would gather around the discussions about the main differences between the tonality-world and the makam-world. A terminology based on the tonality-world will have the potential of bringing misconceptions and transforming effects to the makam-world. Therefore in this study, some terms are particularly and conscientiously used to be able to understand and explain the makam concept more efficiently.

The recent studies reveal that Turkey still possesses a rich material on the makam concept, a live tradition for musical performance and many valuable historical written sources carrying a remarkable terminology that can be utilized to functionally interpret the current musical practices. It can be easily seen that with the support of the researches that should be carried out in this area, it is possible to make critical additions to and revitalizing the Turkish makam theory. The traditional makam conception has been understood and improved on the basis of the melody-oriented theories for centuries. As a conclusion, it is suggested here that the traditional reputation, vitality, functionality and validity of the melodic motion-oriented conception of the makam theory should be returned first and then further improved by reconsidering it.

\section{References}

Abdülbâkî Nâsır Dede. Tedkik u Tahkîk. Nafiz Paşa Yazmaları, No: 1242, Süleymaniye Kütüphanesi, istanbul, 1794.

Ahmad, Feroz. The Making of Modern Turkey. New York: Routledge.

Aksoy, Bülent. "Tanzimat'tan Cumhuriyet'e Musiki ve Batılılaşma." içinde
Tanzimat'tan Cumhuriyet'e Türkiye Ansiklopedisi, C. 5, ed.ler Murat Belge ve Fahri Aral, 1212-1236. İstanbul: iletişim Yayınları, 1985.

Aksoy, Bülent. "Towards the Definition of the Makam." In The Structure and Idea of Maqam: Historical Approaches, 3rd Conference of the ICTM Maqam Study Group, edited by Jürgen Elsner and Risto P. Pennanen, 7-25. Tampere: University of Tampere, 1997.

Aoyagi, Takahiro. "Maqam Rast: Intervallic Ordering, Pitch Hierarchy, Performance, and Perception of a Melodic Mode in Arab Music." PhD diss., University of California, 2001.

Arel, H. Saadettin. Türk Musikisi Nazariyat Dersleri (1943-1948). ed.Onur Akdoğu, Ankara: Kültür Bakanlığı Yayınları, 1993.

Arslan, Fazıl. Safiyüddin-i Urmevi ve Şerefiyye Risalesi. Ankara: Atatürk Kültür Merkezi Yayınları, 2007.

Atcherson, William T. "Theory Accommodates Practice: 'Confinalis' Theory in Renaissance Music Treatises." Journal of the American Musicological Society, 23,no. 2 (1970): 326-330.

Ayangil, Ruhi. "21. Yüzyıl Eşiğinde Türkiye'de Mûsikî Kuramı Çalışmaları." Mûsikişinas, 5 (2001): 72-80.

Ayangil, Ruhi. "Western Notation in Turkish Music." Journal of the Royal Asiatic Society, 18, no. 4 (2008): 401-447.

Bardakçı, Murat. Maragalı Abdülkadir. İstanbul: Pan Yayıncılık, 1986.

Bardakçı, Murat. "Derviş Es-Seyyid Mehmet Emin'in Tanbur Perdeleri Risâlesi." Mûsikîşinas, 4 (2000): 639. 
Bardakçı, Murat. The Treatise of Ahmedogli Şükrullah and Theory of Oriental Music in the 15th Century. Boston: Harvard University Press, 2008.

Barnes, Barry. T. S. Kuhn ve Sosyal Bilimler. Çev. Hüsamettin Arslan. İstanbul: Paradigma Yayıncılık, 2008.

Behar, Cem. Klasik Türk Musikisi Üzerine Denemeler. istanbul: Bağlam Yayınları, 1987a.

Behar, Cem, ed. 18. Yüzyılda Türk Mûsikîsi: Charles Fonton. İstanbul: Pan Yayıncılık, 1987b.

Behar, Cem. Musikiden Müziğe: Osmanlı/Türk Müziği: Gelenek ve Modernlik. istanbul: Yapı Kredi Yayınları, 2005.

Can, M. Cihat. "Türk Müziğinde Makam Kavramı Üzerine Bir inceleme." Yüksek Lisans Tezi, Erciyes Üniversitesi, 1993.

Can, M. Cihat. "15. Yüzyl Türk Musikisi Nazariyatı (Ses Sistemi)." Doktora Tezi, Marmara Üniversitesi, 2001.

Can, M. Cihat "Eski Grek Dört Unsur Nazariyesi ve Türkçe Müzik Yazmalarında Etkisi." GÜGEF Dergisi, 22, no. 2 (2002): 133-143.

Ceyhan, Adem. Bedr-i Dilşad'in Muradnamesi I-II. Ankara: Milli Eğitim Bakanlığı Yayınları, 1997.

Cox, Arnie W. "The Metaphoric Logic of Musical Motion and Space." $\mathrm{PhD}$ diss., University of Oregon, 1999.

Durmaz, Serhad. "Son iki Yüzylda Geleneksel Türk Sanat Musikisinin Makam Dağanndaki Değişmeler." Doktora Tezi, Dokuz Eylül Üniversitesi, 1991.

Durmaz, Serhad ve Yavuz Daloğlu, ed.ler. Gültekin Oransay Derlemesi 1. İzmir: D\&D Yayınları, 1990.
Dzhumajev, Alexander. "From Parda to Maqam: A Problem of The Origin of The Regional Systems." In Regionale Maqam-Traditionen in Geschichte und Gegenwart edited by Elsner \& Jahnichen (145-162), Berlin: Nationalkomitee DDR, 1992.

Ederer, Eric B. "The Theory and Praxis of Makam in Classical Turkish Music 1910-2010." PhD diss. University of California, Santa Barbara, 2011.

Elsner, Jürgen, ed. Maqam - Raga - Zeilenmelodik: Konzeptionen und Prinzipien der Musikproduktion. Berlin, 1989.

Elsner, Jürgen \& Gisa Jahnichen, eds. Regionale Maqam-Traditionen in Geschichte und Gegenwart. Berlin, 1992.

Elsner, Jürgen \& Risto P. Pennanen, eds. The Structure and Idea of Maqam Historical Approaches. Tanpere: University of Tanpere, 1997.

Elsner, Jürgen \& Gisa Jahnichen, eds. Maqam Traditions of Turkic Peoples. Berlin: Trafo, 2006.

Elsner, Jürgen \& Gisa Jahnichen, eds. Intercultural Comparison of Maqam and Related Phenomena. Berlin: Trafo, 2008.

Elsner, Jürgen, Gisa Jahnichen, \& Jasmina Talam, eds. Maqam: Historical Traces and Present Practice in Southern European Music. Cambridge: Cambridge Scholars Publishing, 2014.

Elsner, Jürgen, Gisa Jahnichen, \& Cenk Güray, eds.) Maqam Traditons between Theory and Contemporary Music Making. İstanbul: Pan Yayıncılik, 2016.

Esseyid Mehmed Emin. Kavâid-i Nağme$i$ Perde-i Tanbur. Adnan Ötüken 
Kolleksiyonu, No: 131/3, Milli Kütüphane, Ankara.

Ezgi, Suphi Z. Nazari Ameli Türk Musikisi, IV. Kitap. istanbul: istanbul Konservatuarı Yayını, 1953.

Fallahzadeh, Mehrdad. Persian Writings on Music: A Study of Persian Musical Literature from 1000 to $1500 \mathrm{AD}$. Upsala: Upsala Universitet Press, 2005.

Farhat, Hormoz. The Dastgah Concept in Persian Music. Cambridge: Cambridge University Press, 2004.

Farmer, Henry G. Studies in Oriental Music. edited by Eckhard Neubauer. Frankfurt Am-Main: IGAIW an der J. W. Goethe-Universitat, 1986.

Feldman, Walter Z. Music at the Ottoman Court: Makam, Composition and the Early Repertoire. Berlin: VWB Verlag für Wissenschaft und Bildung, 1996.

Godwin, Joscelyn. The Harmony of the Spheres. Rochester: Inner Traditions International, 1993.

Güray, Cenk. Bin Yılın Mirası, Makamı Var Eden Döngü: Edvar Geleneği. İstanbul: Pan Yayıncılık, 2011.

Hatipoğlu, Emrah. Mevlevi Ayinleri: Makamlar ve Geçkiler. ìstanbul: T.C. Konya Valiliği Yayınları, 2011.

Hızır bin Abdullah. Kitab-ı Edvar. Revân Kolleksiyonu, No: 1728, Topkapı Sarayı Müzesi Kütüphanesi, İstanbul, 1441.

ilerici, Kemal. "Türk Müziğinin Bütünlüğü Üzerine." II. Milletlerarası Türk Folklor Kongresi Bildirileri, III. Cilt. Ankara: KTB MiFAD Yayınları, 1983.

Kantemiroğlu (Dimitrie Cantemir). Kitâbu ilmü'l-Mûsikî alâ vechi'lHurufât. Ed.Yalçın Tura. ìstanbul: Yapı Kredi Yayınları, 2001.
Karadeniz, Ekrem. Türk Musikisi'nin Nazariye ve Esaslan. Ankara: İş Bankası Yayınları, 1984.

Kemânî Hızır Ağa. Tefhîmü'l-Makâmât fî Tevlîdü'n-Nagâmât. Hazine, No: 1793, Topkapı Sarayı Müzesi Kütüphanesi, İstanbul.

Kırşehirli Nizamoğlu Yûsûf. Mûsikî Risâlesi. Adnan Ötüken Kolleksiyonu, No: 131/1, Milli Kütüphane, Ankara.

Knysh, Alexander. Islamic Mysticism: A Short History. Leiden: Brill, 1999.

Kuhn, Thomas. The Structure of Scientific Revolutions. Chicago: The University of Chicago Press, 1970.

Mardin, Şerif. Türk Modernleşmesi. İstanbul: iletişim Yayınları, 1999.

Mehmed Haşim Bey. Mecmua-i Kârhâ, Nâkışhâ ve Şarkiyyat. İstanbul, 1864.

Nettl, Bruno. " World Music in the Twentieth Century: A Survey of Research on Western Influence." Acta Musicologica, 58, no. 2 (1986): 360373.

Oransay, Gültekin. "Türk Din Musikisi Tür, Makam ve Usullarının Kodlanması." Ankara Üniversitesi ilahiyat Fakültesi Dergisi, 21 (1976): 152183.

Özkan, İsmail H. Türk Musikisi Nazariyatı ve Usulleri. ìstanbul: Ötüken Neşriyat, 1987.

Öztürk, Okan M. Zeybek Kültürü ve Müziği. istanbul: Pan Yayıncılık, 2006.

Öztürk, Okan M. "Büzürg Makamı: Türk Müziğinde Bütüncül Kuram ihtiyacı Icçin Analitik Bir Model." Türk Müziğinde Uygulama-Kuram Sorunlan ve Çözüm Önerileri Bildiriler Kitabı, İstanbul, 2008: 89-130. 
Öztürk, Okan M. "15. Yüzyıl Osmanlı Mûsikîsinde şûbe Kavramı ve Hermetik Gelenek." Doğu Batı Dergisi, 62 (2012a): 115-140.

Öztürk, Okan M. "Hızır Bin Abdullah'ta Saz Düzenleri Ve Yansıttığı Ses Sistemi Üzerine Tespitler." Porte Akademik, 3, no. 2 (2012b): 109-128.

Öztürk, Okan M. "Makam, Âvâze, şûbe ve Terkib: Osmanlı Mûsikî Nazariyatında Pisagorcu Kürelerin Uyumu/Mûsikîsi Anlayışının Temsili." Rast Uluslararası Müzikoloji Dergisi, 2, no. 1 (2014a): 1-49.

Öztürk, Okan M. The Concept of şûbe ('Branch') as a Tetrachordal Classification Method in the 15th Century Ottoman Makam Theory." In Maqam: Historical Traces and Present Practice in Southern European Music, edited by Jürgen Elsner et al., (20-42), Cambridge: Cambridge Scholars Publishing, 2014b.

Öztürk, Okan M. "Makam Müziğinde Ezgi ve Makam ilişkisinin Analizi ve Yorumlanması Açısından Yeni Bir Yaklaşım: Perde Düzenleri ve Makamsal Ezgi Çekirdekleri." Doktora Tezi, İstanbul Teknik Üniversitesi, 2014c.

Öztürk, Okan M. "The Conception of Contemporizing Music in the Founding Ideology of Early Republican Turkey: A Critical Approach", In In Which Direction is Music Heading: Cultural and Cognitive Studies in Turkey, edited by Firat Kutluk \& Uğur Türkmen, 75-108. New Castle: Cambridge Scholars Publishing, 2015a.

Öztürk, Okan M. "The Place of the Concept of Melodic Motion in the Ideas of Makam and Mode." In IVth International Musicological Symposium Space of Mugham, edited by Suraya
Agayeva, 293-305. Baku: Şerk-Gerb Neşriyyat Evi, 2015b.

Öztürk, Okan M. "Halk Musikisi Repertuar İncelemelerinin Makam Nazariyesi Araştırmalarına Yapabileceği Katkılar." Ege Üniversitesi DTMK Dergisi, 7 (2015c): 1-29.

Öztürk, Okan M. "Two Key Subjects For Maqam Theory: The Fret System And Tunings", In Maqam Traditons Between Theory and Contemporary Music Makingi edited by Jürgen Elsner et al., 213-238. istanbul: Pan Yayıncılık, 2016a.

Öztürk, Okan M. "Makam Eğitiminde Düzenler ve Nağmeler Nazariyesinin Yeni Bir Yöntem Olarak Kullanılabilirliği." içinde Müzikte Metodoloji Ve Müzik Teknolojileri Sempozyum Bildiriler Kitabı, edited by Göktan Ay, 179-193. İstanbul: Avcılar Belediye Konservatuarı Yayınları, 2016b.

Öztürk, Okan M. "Osmanlı Mûsikîsinde 'Havas Beğenisine Mahsusiyet'in Tezahürü Olarak Klasik Üslûp", is tanbul Üniversitesi Sosyoloji Dergisi, 37, no. 2 (2017): 343-378.

Öztürk, Okan M. "The Concept of Makam-Based Melody and Its Problematic in Musical Analysis". In Turkic Soundscapes: From Shamanic Voices to Hip-Hop, edited by Razia Sultanova and Megan Rancier, 1940. London: Routledge, 2018a.

Öztürk, Okan M. "Dârülelhân Sürecinde Garpçıların Şark Mûsikîsiyle Baş Etme Stratejileri", Konservatoryum Dergisi, (2018b).

Pappas, Miltiadis. "Kiltzanidis'in Kitabı." Yüksek Lisans Tezi, İstanbul Teknik Üniversitesi, 1997. 
Pappas, Miltiadis. "Apostolos Konstasín Nazariyat Kitabı." Doktora Tezi, istanbul Teknik Üniversitesi, 2007.

Popescu-Judetz, Eugenia. Meanings in Turkish Musical Culture. istanbul: Pan Yayıncilık, 1996.

Popescu-Judetz, Eugenia. Prince Dimitrie Cantemir. Istanbul: Pan Yayıncılık, 1999.

Popescu-Judetz, Eugenia. Sources of Eigteenth Century Music. istanbul: Pan Yayıncılık, 2000.

Popescu-Judetz, Eugenia. Tanburi Küçük Artin. İstanbul: Pan Yayıncılık, 2002.

Popescu-Judetz, Eugenia. Seydi's Book On Music. Frankfurt Am-Main: IGAIW an der J. W. GoetheUniversitat, 2004.

Powers, Harold. "Mode." In The New Grove Dictionary of Music and Musicians, edited by Stanley Sadie, London: Macmillan Publishers, 1980.

Powers, Harold. "Tonal Types and Modal Categories in Renaissance Polyphony." Journal of the American Musicological Society, 34, no. 3 (1981): 428-470.

Powers, Harold. "First Meeting of the ICTM Study Group on Maqam." Yearbook for Traditional Music, 20 (1988): 199-218.

Seydî. Matla. III Ahmed Koleksiyonu, No: 3459, Topkapı Sarayı Müzesi Kütüphanesi, istanbul, 1504.

Sezikli, Ubeydullah. "Abdülkadir Meragî ve Camiü'I-Elhan'ı." Doktora Tezi, Marmara Üniversitesi, 2007.

Shaw, Stanford. History of The Ottoman Empire and Modern Turkey V. II. Cambridge: Cambridge University Press, 1977.
Shehadi, Fadlou. Philosophies of Music in Medieval Islam. Leiden: Brill, 1995.

Shiloah, Amnon. The Theory of Music in Arabic Writings (c. 900-1900). München: G. Henle Verlag, 1979.

Signell, Karl. Makam: Modal Practice in Turkish Art Music. Seattle: Asian Music Publications, 1977.

Signell, Karl. "Contemporary Turkish Makam Practise." In The Middle East /Garland Encyclopedia Of World Music, Volume 6/, edited by Virginia Danielson et al., 45-58. Oxon: Routledge, 2002.

Signell, Karl. "Re-Vitalizing Turkish Theory." içinde Türk Müziğinde Uygulama-Kuram Sorunlan Ve Çözüm Önerileri Bildiriler Kitabı, ed.ler Göktan Ay ve Lale Berköz, 183-202. istanbul: Kültür Aş Yayınları, 2008.

Stubbs, Frederick. W. "The Art and Science of Taksim: An Empirical Analysis of Traditional Improvisation from 20th century Istanbul." $\mathrm{PhD}$ diss. Wesleyan University, 1994.

Tanrıkorur, Cinuçen. Türk Müzik Kimliği. İstanbul: Dergah Yayınları, 1998.

Tekin, Abdülkadir. "Hızır Ağa'nın 'Musiki Risalesi' isimli Yazma Eserinin Transkripsiyonu ve Dönemin Edvarlan ile Mukayesesi." Yüksek Lisans Tezi, Dokuz Eylül Üniversitesi, 2003.

Tekin, Hakkı. "Lâdikli Mehmet Çelebi ve Er-Risaletül-Fethiyye'si." Doktora Tezi, Niğde Üniversitesi, 1999.

Tırışkan, Ahmet G. "Haşim Bey'in Edvan." Yüksek Lisans Tezi, isstanbul Teknik Üniversitesi, 2000.

Titon, Jeff T. \& Mark Slobin, eds. Worlds of Music. New York: Schirmer Books, 1997. 
Tura, Yalçın. "Türk Halk Musikisindeki Makam Hususiyetleri ve Bunların Dayandığı Ses Sistemi." icçinde III. Milletlerarası Türk Folklor Kongresi Bildirileri III. Cilt. Ankara: Kültür Bakanlığı MiFAD Yayınları, 1987.

Tura, Yalçın. Türk Musikisinin Meseleleri. İstanbul: Pan Yayıncılık, 1988.

Tura, Yalçın. "Türk Halk Müziğinde Karşılaşılan Ezgi Çizgilerinin İncelenmesi ve Sınıflandırılması." içinde V. Milletlerarası Türk Halk Kültürü Kongresi. Ankara: Kültür Bakanlığı HAGEM Yayınları, 1997.

Turabi, Ahmet H. "El-Kındi'nin Musiki Risaleleri." Yüksek Lisans Tezi, Marmara Üniversitesi, 1996.

Turabi, Ahmet H. ibn-i Sina Musiki, İstanbul: Literatür Yayınları, 2004.

Turabi, Ahmet H. Gevrekzade Hafiz Hasan Efendi ve Musiki Risalesi. ìstanbul: Rağbet Yayınları, 2005.

Uslu, Recep. Saraydaki Kemancı, İstanbul: (personal printing), 2009.

Uygun, M. Nuri. "Kadızade Tirevi ve Musiki Risalesi." Yüksek Lisans Tezi, Marmara Üniversitesi, 1990.

Uygun, M. Nuri. Safiyüddin Abdulmu'min Urmevi ve 'Kitabu'l-Edvar'. İstanbul: Kubbealtı Neşriyatı, 1996.

Uz, Kazım. Musiki Istılahatı. ed. Gültekin Oransay. Ankara: Küğ Yayını, 1964.

Uzdilek, Salih M. Ilim ve Mûsikî. İstanbul: Kültür Bakanlığı Yayınları, 1977.

Wright, Owen. The Modal System of Arab and Persian Music A.D. 1250 1300. Oxford: Oxford University Press, 1978.

Wright, Owen. "Çargâh in Turkish Classical Music: History versus Theory", Bulletin of the School of Oriental and African Studies (SOAS), 53, no. 2 (1990): 224-244.

Wright, Owen. Demetrius Cantemir: The Collection of Notations $V .1$ Text. London: SOAS Publications, 1992.

Wright, Owen. Demetrius Cantemir: The Collection of Notations V. 2 Commentary. London: SOAS Publications, 2000.

Yavuzoğlu, Nail. 21. Yüzylda Türk Müziği Teorisi. ìstanbul: Pan Yayıncılık, 2008.

Yekta, Rauf. Türk Musikisi Nazariyatı. İstanbul: Mahmud Bey Matbaası, 1924.

Yekta, Rauf. Türk Musikisi (1922). Çev. Orhan Nasuhioğlu. istanbul: Pan Yayıncılık, 1986.

Yılmaz, Oya L. "XIII. Yüzyıldan Günümüze Kadar Varlığını Sürdüren Makamlar ve Değişim Çizgileri." Doktora Tezi, Gazi Üniversitesi, 2002. 